\title{
A Rare Abdomino-Pelvic Tumor: Paraganglioma
}

\author{
Um Caso Raro de Tumor Abdominopélvico: Paraganglioma
}

\author{
Célia PEDROSO ${ }^{1}$, Raquel ROBALO ${ }^{1}$, Pedro SERENO ${ }^{1}$, Carlos BARROS ${ }^{1}$, Carlos MARQUES ${ }^{1}$ \\ Acta Med Port 2015 Jan-Feb;28(1):114-116
}

\section{ABSTRACT}

Paragangliomas are rare tumors, with a reported incidence of 2-8 per million. They are chromaffin cell tumors that develop from the neural crest cells and may be divided in tumors derived from the parasympathetic or sympathetic ganglia. We report a case a of a 32-year-old nulliparous woman, referred to our Infertility Clinic. Abdomino-pelvic ultrasound identified a large abdominopelvic tumor, without ovarian origin (both ovaries were identified and had normal morphology). Magnetic Resonance Imaging suggested a right adnexal multicystic, vascularized mass close to iliac vessels and questioning an ovarian origin. At exploratory laparotomy, a $10 \mathrm{~cm}$ encapsulated and vascularized mass was found beginning just below right renal artery and extending to the level of the broad ligament. This mass was totally excised and histopathology was consistent with Paraganglioma.

Keywords: Abdominal Neoplasms; Paraganglioma; Pelvic Neoplasms.

\section{RESUMO}

Os paragangliomas são tumores raros com uma incidência descrita de 2-8 por milhão. São tumores de células cromafins do sistema neuroendócrino que provêm dos gânglios simpáticos ou parassimpáticos. Apresentamos um caso de uma jovem de 32 anos, nulípara referenciada à nossa Unidade de Infertilidade. No decurso da investigação, na ecografia abdomino-pélvica identificámos a presença de uma massa que se estendia da pélvis ao abdómen, desde ovário direito até junto dos vasos renais, cujo ponto de partida era extra-ovárico (foram identificados os dois ovários com características morfológicas normais). A ressonância magnética revelou uma massa anexial multiquística e muito vascularizada junto aos vasos ilíacos, tendo colocado em hipótese origem ovárica. Desta forma, procedemos a uma laparotomia exploradora e encontrámos uma massa encapsulada, muito vascularizada que se estendia desde o bordo inferior da artéria renal direita até ao ligamento largo direito. A massa foi totalmente removida e a histologia foi consistente com um Paraganglioma.

Palavras-chave: Neoplasias Abdominais; Neoplasias Pélvicas; Paraganglioma.

\section{INTRODUCTION}

Paragangliomas are rare tumors, with a reported incidence of $2-8$ per million. ${ }^{1}$ They are chromaffin cell tumors that develop from the neural crest cells and may be divided in tumors derived from the parasympathetic or sympathetic ganglia. These tumors comprise $10-18 \%$ of all chromaffin tumor. ${ }^{2}$ Parasympathetic ganglia-derived tumors are found almost exclusively in the neck and skull base and arise within the carotid body and globus jugulotympanic. The best known and most common sympathetic gangliaderived tumors grow within the adrenal medulla and are known as pheochromocytoma. In contrast, sympathetic paragangliomas, also known as extraadrenal pheochromocytomas, arise outside the adrenal gland and can be found anywhere along the sympathetic chain from the base of the skull and neck ( $5 \%$ of cases) to the bladder and prostate gland $(10 \%)$. Of those found along the aorta, $10 \%$ are in the thorax and $75 \%$ are in the abdomen, with most of the latter located in the organ of Zuckerkandl (centered around the root of the inferior mesenteric artery).

The authors report a case of a large inferior para-aortic paraganglioma in a 32-year-old woman.

\section{CASE REPORT}

A 32-year-old healthy nulliparous woman with a history of primary infertility of 2 years followed at our Infertility Clinic was submitted to routine pelvic ultrasound study which revealed a uterus with 3 small fibroids, normal right ovary and a large abdominopelvic mass of solid and cystic nature, measuring $64.4 \times 52.6 \times 57.1 \mathrm{~mm}$ (Fig.s 1 and 2).

The tumor was vascularized and independent from the right ovary; there were no signs of ascitis or hydronephrosis. Magnetic Resonance Imaging (MRI) revealed a multicystic, vascularized adnexal mass with $60 \times 35 \times 104 \mathrm{~mm}$ located close to the iliac vessels and questioning a right ovarian origin. Although the patient had a normal body mass index her first physical examination did not reveal any abdomino pelvic mass. Evaluation of blood pressure was also normal. Blood tests showed normal values, including tumor markers levels such as carcinoembryonic antigen, carbohydrate antigen 125, and $\alpha$-feto-protein. Based on magnetic resonance imaging report the patient was offered an exploratory laparotomy.

At surgery a $10 \mathrm{~cm}$ encapsulated and vascularized solid and cystic mass was found beginning just below right renal artery and extending to the level of the broad ligament. Both ovaries were morphologically normal. The tumor was completely excised (Fig. 3).

1. Department of Obstetrics and Gynecology. Alfredo da Costa Maternity. Lisbon. Portugal.

Recebido: 04 de Junho de 2014 - Aceite: 14 de Outubro de 2014 | Copyright $\odot$ Ordem dos Médicos 2015 


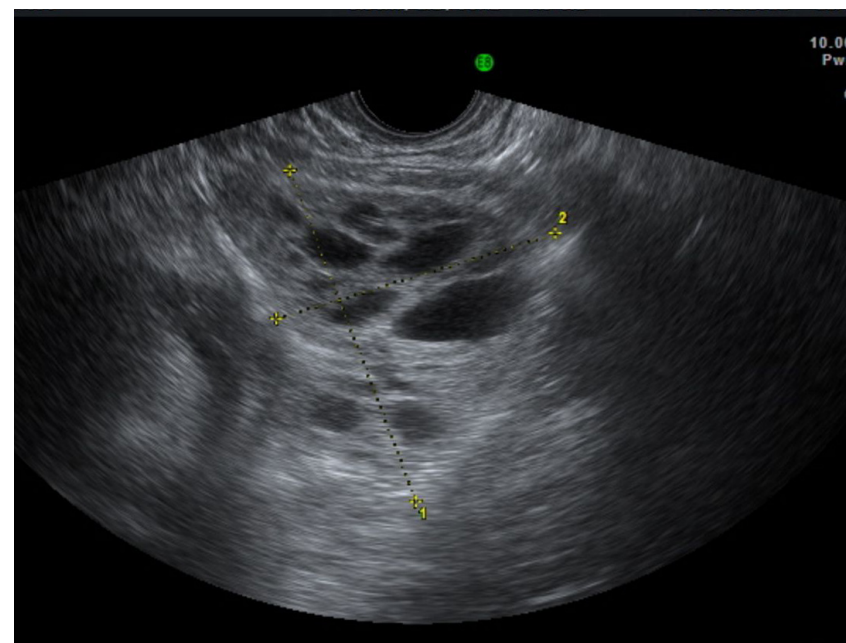

Figure 1 - Pelvic Ultrasound: image of a solid and cystic mass in the pelvis

Histopathology revealed a solid tumor of $11.5 \times 6.5 \times$ $5.5 \mathrm{~cm}$, nests of cells with a trabecular and alveolar pattern consistent with a Paraganglioma (Fig.s 4 and 5).

\section{DISCUSSION}

Paraganglioma is the generic term applied to tumors of paraganglia regardless of location. Paragangliomas of the adrenal medulla, the most common site of paragangliomas, are known as pheochromocytomas while those located outside the adrenal gland are known as extra-adrenal pheochromocytomas/paragangliomas. ${ }^{3,4}$

Extra-adrenal paraganglia are divided into two categories: those related to the parasympathetic system and those connected with the sympathetic system. The former, usually nonchromaffin, are found mainly along the supradiaphragmatic branches of the vagus and glossopharyngeal nerves and are believed to have a chemoreceptor function. ${ }^{3}$ The latter are chromaffin, associated with the peripheral sympathetic nervous system, and produce catecholamines

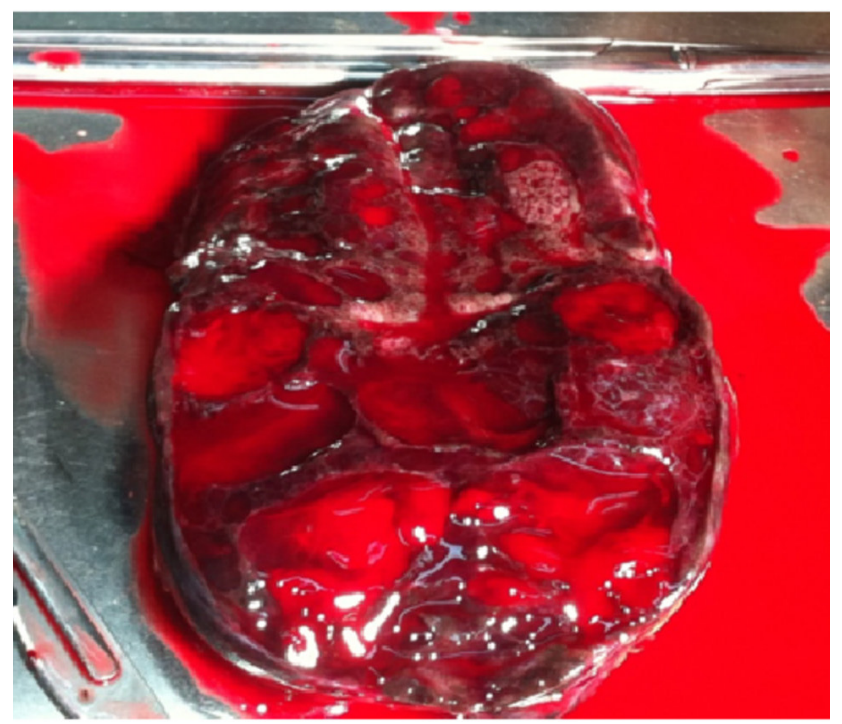

Figure 3 - Paraganglioma: longitudinal section (note the similarity with ultrasound images)

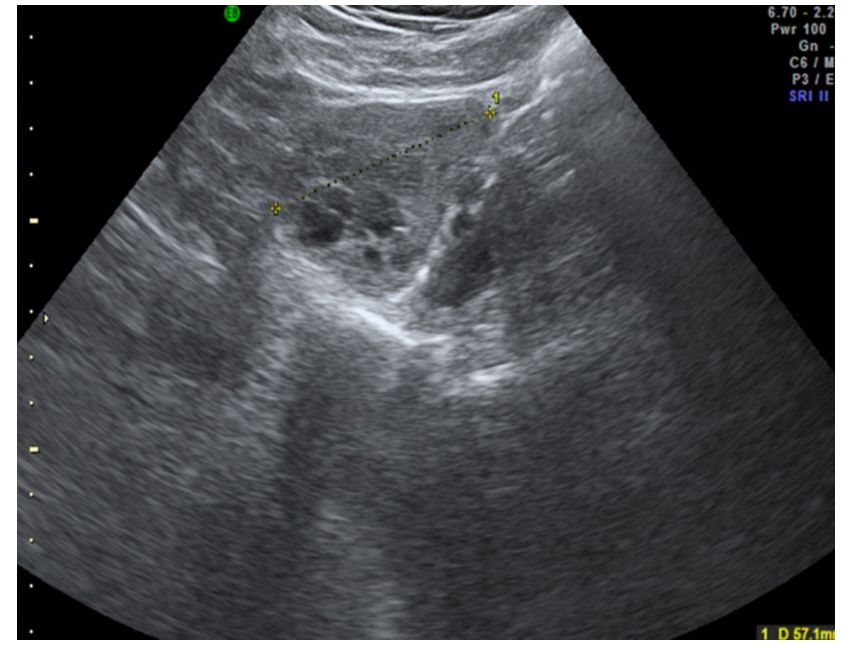

Figure 2 - Abdominal Ultrasound: image of the same solid and cystic mass in the abdomen

in response to sympathetic neural stimulation. They lie along the thoracolumbar paravertebral region, from high in the neck, near the superior cervical ganglion to the abdomen and pelvis, predominantly in the posterior mediastinum and retroperitoneum. ${ }^{5,6}$

Rarely, paragangliomas have been described in unusual sites, such as the gallbladder, mesentery, kidney, prostate and ovary. The paraganglioma in our patient was located in the area of Zuckerkandl organ, extending to the pelvic cavity.

Most paragangliomas are diagnosed in the third to fifth decade of life. ${ }^{2}$ Extra-adrenal paragangliomas present with abdominal pain and/or palpable abdominal mass ${ }^{7}$ however, they may be asymptomatic even when associated with large masses, as our patient. About $15 \%$ of patients are asymptomatic and the diagnosis is usually done in the context of diagnostic imaging procedures for other purposes (incidentalomas). ${ }^{1}$ Other symptoms include nausea, vomiting, diarrhea, abdominal distension and weight loss.

The majority of abdominal pheocromocytomas and paragangliomas are benign; malignant pheochromocytomas account for nearly $10 \%$ of all pheochromocytomas.

Clinical, biochemical and radiological features are inadequate to predict malignancy ${ }^{8-10}$ which can be established by the presence of distant metastases mainly to the liver, lymph nodes, lung and/or bone, either at diagnosis or during follow-up. ${ }^{11}$ Local invasion and various histopathological features can be suggestive; however, these features are not widely accepted and there is a need for the development of more sensitive and specific diagnostic means. ${ }^{12,13}$ This said, the lack of firm predictors of malignancy, coupled with the variable course of this rare disease, make life-long followup of patients with chromaffin-cell tumors mandatory.

Contrast-enhanced abdominal computed tomography (CT) scan is useful for diagnosis; however, there are no specific features for this condition. Abdominal MRI and scintigraphy performed with radiotracer-labeled metaiodobenzylguanidine (MIBG) are essential in the identification and characterization of paragangliomas 


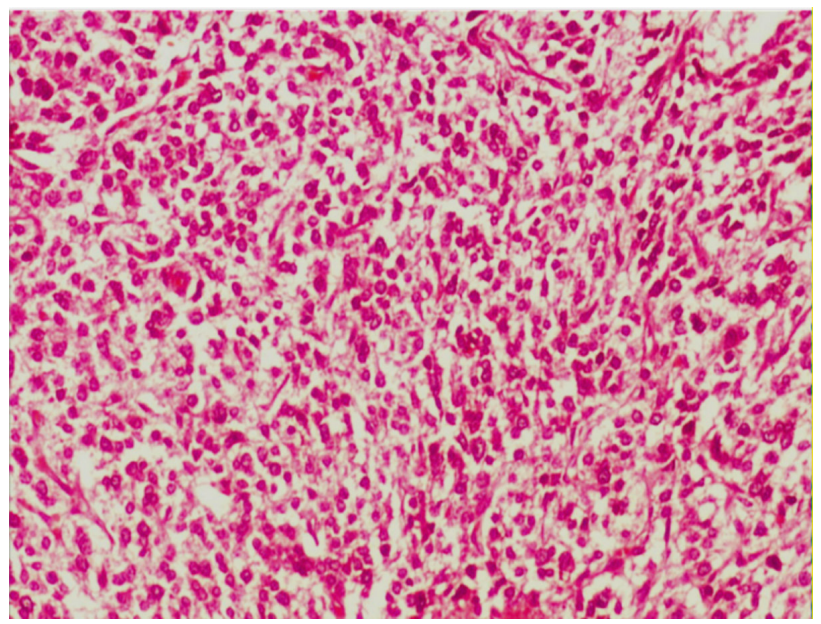

Figure 4 - Histopathology: Paraganglioma (trabecular pattern)

(distinguishing functional from non-functional tumors). MRI has the highest sensitivity in detection of extra-adrenal paragangliomas and pheochromocytomas. ${ }^{7}$

The primary treatment for paragangliomas is complete surgical resection. Conventional treatment consists of open exploration and resection of the mass. Annual biochemical testing (plasma catecholamines, plasmafree metanephrines, urinary catecholamines, urinary vanillylmandelic acid, urinary total metanephrines, and urinary fractionated metanephrines), CT scans and/or MRI and MIBG scans are essential in the assessment for metastatic disease, tumor recurrence or delayed appearance of multiple primary tumors. ${ }^{14}$

\section{CONCLUSION}

Paraganglioma of the abdomino-pelvic cavity is an extremely rare tumor. Clinical and imaging data of patients with extra-adrenal, intra-abdominal paragangliomas are variable. Many of them may be asymptomatic even when the lesion is quite large.

It may appear as an incidental finding on gynecological ultrasound examination, especially in a tertiary women's

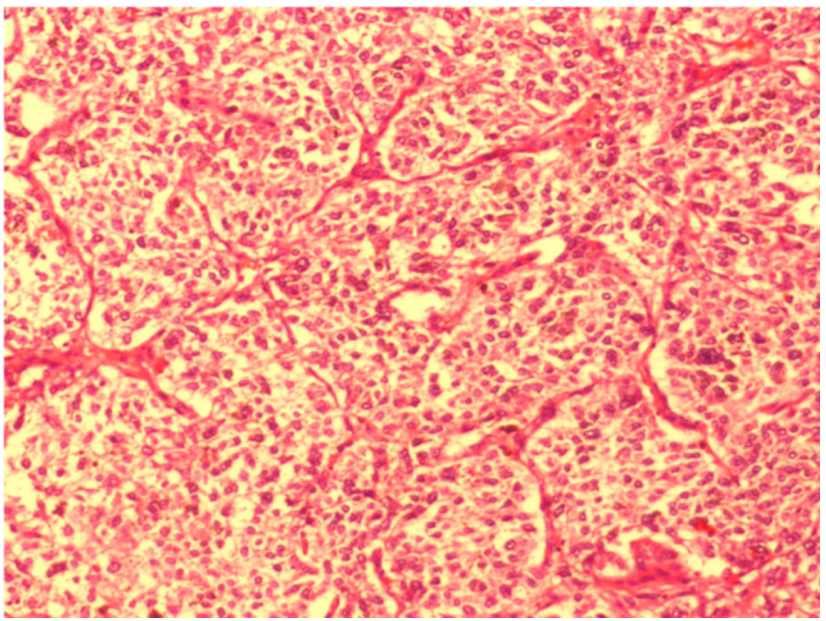

Figure 5 - Histopathology: Paraganglioma (alveolar pattern)

hospital such as ours.

These cases highlight how paraganglioma may be mistaken for gynecological masses. A careful approach during sonography, depending on the operator, may in some cases better exclude the ovarian origin of adnexal masses than MRI. Although it is important not to forget that MRI is important in differential diagnosis of adnexal masses and has the highest sensivity in detection of extra-adrenal paragangliomas and pheochromocytomas.

\section{ACKNOWLEDGMENTS}

The authors wish to thank Duarte Rosa, for his cooperation in taking the photographs that illustrate this paper. The authors also thank the images of histopathology service.

\section{CONFLITS OF INTEREST}

The authors declare that there are no conflicts of interest.

\section{FUNDING SOURCES}

No subsidies or grants contributed to this work.

prospects. Endocr Rev. 2003;24:539-53.

1. Petri BJ, van Eijck C, Herder WW, Wagner A, Krijger RR. Pheochromocytomas and sympathetic paragangliomas. $\mathrm{Br} \mathrm{J}$ Surg. 2009;96:1381-92.

2. Lee JA, Duh Q-Y. Sporadic paraganglioma. World J Surg. 2008;32:6837 .

3. Chetty R. Familial paraganglioma syndromes. J Clin Pathol. 2010;63:488e-91.

4. Huan L, Jetly R, Kandil E. Paraganglioma of the organ of Zuckerkandl. J La State Med Soc. 2012;164:26-30.

5. Young W. Paragangliomas clinical overview. Ann N Y Acad Sci. 2006;1073:21-9.

6. Lee $\mathrm{K}$, Whan Oh $\mathrm{Y}$, Jun Noh $\mathrm{H}$, Jin Lee $\mathrm{Y}$, Yong $\mathrm{H}$, Kang $\mathrm{E}$, et al. Extraadrenal paragangliomas of the body: imaging features. Am $\mathrm{J}$ Roentgenol. 2006;187:492-504.

7. Archontovasilis F, Markogiannakis H, Dikoglou C, Drimousis P, Toutouzas $\mathrm{K}$, Theodorou $\mathrm{D}$, et al. Paraganglioma of the greater omentum: case report and review of the literature. World J Surg Oncol. 2007;5:1-6.

8. Bravo EL, Tagle R. Phaeochromocytoma: state of the art and future
9. Kaltsas GA, Papadogias D, Grossman AB. The clinical presentation (symptoms and signs) of sporadic and familial chromaffin cell tumours (phaeochromocytomas and paragangliomas). Front Horm Res. 2004;31:61-75

10. Ahlman $\mathrm{H}$. Malignant phaeochromocytoma. State of the field with future projections. Ann N Y Acad Sc. 2006;1073:449-64.

11. Goldstein RE, O'Neill JA. Holcomb GW, Morgan WM, Neblett WW, Oates JA, et al. Clinical experience over 48 years with phaeochromocytoma. Ann Surg. 1999;229:755-66.

12. Eisenhofer G, Bornstein S, Brouwers F, Cheung NV, Dahia PL, Krijger $\mathrm{RR}$, et al. Malignant phaeochromocytoma: current status and initiatives

13. Eisenhofer G, Lenders J, Pacak K. Phaeochromocytoma, pathophysiology and clinical management. Front Horm Res. 2004;31:76-106.

14. Disick GI, Palese MA. Extra-adrenal pheochromocytoma: diagnosis and management. Curr Urol Rep. 2007;8:83-8. for future progress. Endocr Relat Cancer. 2004;11:423-36. 


\section{A Rare Abdomino-Pelvic Tumor: Paraganglioma}

Acta Med Port 2015:28:114-116

Publicado pela Acta Médica Portuguesa, a Revista Científica da Ordem dos Médicos

Av. Almirante Gago Coutinho, 151

1749-084 Lisboa, Portugal.

Tel: +351218428 215

E-mail: submissao@actamedicaportuguesa.com

www.actamedicaportuguesa.com

ISSN:0870-399X | e-ISSN: 1646-0758

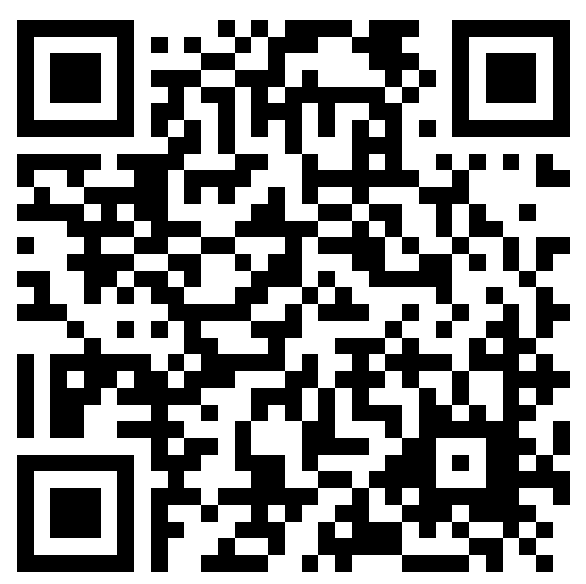

